University of Nebraska - Lincoln

DigitalCommons@University of Nebraska - Lincoln

College of Law, Faculty Publications

Law, College of

1997

\title{
Methylenetetrahydrofolate Reductase: Comparison of the Enzyme from Mammalian and Bacterial Sources
}

\author{
Christal A. Sheppard \\ University of Nebraska-Lincoln, christalsheppard@unl.edu \\ James S. Sumner \\ Merck \& Co., Inc., West Point, NY \\ Phillipe Goyette \\ McGill University, Montreal, QC \\ Phyllis Frosst \\ McGill University, Montreal, QC \\ Rima Rozen \\ McGill University, Montreal, QC \\ See next page for additional authors
}

Follow this and additional works at: https://digitalcommons.unl.edu/lawfacpub

Part of the Legal Studies Commons

Sheppard, Christal A.; Sumner, James S.; Goyette, Phillipe; Frosst, Phyllis; Rozen, Rima; and Matthews, Rowena G., "Methylenetetrahydrofolate Reductase: Comparison of the Enzyme from Mammalian and Bacterial Sources" (1997). College of Law, Faculty Publications. 120.

https://digitalcommons.unl.edu/lawfacpub/120

This Article is brought to you for free and open access by the Law, College of at DigitalCommons@University of Nebraska - Lincoln. It has been accepted for inclusion in College of Law, Faculty Publications by an authorized administrator of DigitalCommons@University of Nebraska - Lincoln. 


\section{Authors}

Christal A. Sheppard, James S. Sumner, Phillipe Goyette, Phyllis Frosst, Rima Rozen, and Rowena G. Matthews 


\title{
Methylenetetrahydrofolate Reductase: Comparison of the Enzyme from Mammalian and Bacterial Sources
}

\author{
Christal A. Sheppard, ${ }^{1}$ James S. Sumner, ${ }^{2}$ Phillipe Goyette, ${ }^{3}$ \\ Phyllis Frosst, ${ }^{3}$ Rima Rozen, ${ }^{3}$ and Rowena G. Matthews ${ }^{1}$ \\ 1. University of Michigan, Ann Arbor, MI \\ 2. Merck \& Co., Inc., West Point, NY \\ 3. McGill University, Montreal, QC
}

\begin{abstract}
Methylenetetrahydrofolate reductase catalyzes the reduction of methylenetetrahydrofolate to methyltetrahydrofolate, which serves as the methyl donor for the conversion of homocysteine to methionine in the reaction catalyzed by methionine synthase. Recent studies have provided evidence for association of a common polymorphism of methylenetetrahydrofolate reductase with elevated levels of blood homocysteine, a metabolite correlated with increased cardiovascular risk in humans. In this chapter, we review earlier studies on the properties of the mammalian enzyme, interpreting these observations in the light of the deduced amino acid sequence for the human enzyme. The catalytic portion of the human enzyme shows significant sequence homologies with methylenetetrahydrofolate reductase from bacterial sources, and in particular mutations that are known to cause elevated blood homocysteine levels in humans affect residues that are conserved in the bacterial enzyme. Thus we believe that studies of mutant $E$. coli proteins will provide valuable information on the consequences of human mutations of equivalent residues.
\end{abstract}

\section{Properties of Mammalian Methylenetetrahydrofolate Reductase}

The conversion of homocysteine to methionine requires a sequence of three enzymatic reactions, which are catalyzed by serine hydroxymethyltransferase (41), methylenetetrahydrofolate reductase (MTHFR [4-2]), and cobalamin-dependent methionine synthase (4-3), respectively.

$$
\begin{gathered}
\text { Serine }+\mathrm{H}_{4} \text { folate } \rightarrow \text { Glycine }+\mathrm{CH}_{2}-\mathrm{H}_{4} \text { folate } \\
\mathrm{CH}_{2}-\mathrm{H}_{4} \text { folate }+\mathrm{NADPH} \rightarrow \mathrm{CH}_{3}-\mathrm{H}_{4} \text { folate }+\mathrm{NADP}^{+} \text {(2) } \\
\mathrm{CH}_{3}-\mathrm{H}_{4} \text { folate }+ \text { Homocysteine } \rightarrow \mathrm{H}_{4} \text { folate }+ \text { Methionine }
\end{gathered}
$$

The combined action of these three enzymes results in the methylation of homocysteine by transfer of a methyl group derived from the $\beta$-carbon of serine. Methionine can be converted to adenosylmethionine (AdoMet) by adenosylmethionine synthetase, as shown in (4). AdoMet is an activated methyl donor, and serves to provide methyl groups in a wide variety of biological methylation reactions.

$$
\text { Methionine }+ \text { ATP } \rightarrow \text { AdoMet }+ \text { tripolyphosphate }
$$

Methylenetetrahydrofolate reductase has been purified from a variety of bacterial and mammalian sources and has been shown to contain enzyme-bound FAD as a prosthetic group [1-6]. The flavin plays an essential role in the catalytic reaction. In the porcine enzyme, which has been purified to homogeneity [6] and extensively studied, NADPH stoichiometrically reduces the flavin as indicated in (5).

$$
\mathrm{FADPH}+\mathrm{E} \cdot \mathrm{FAD}_{\mathrm{ox}} \rightarrow \mathrm{NADP}^{+}+\mathrm{E} \cdot \mathrm{FAD}_{\text {red }}
$$

This reaction is irreversible both in vivo and in vitro [7], and imparts irreversibility to the entire reaction shown in (2). In the physiologic reaction, the reduced 
enzyme-bound flavin is oxidized by methylenetetrahydrofolate $\left(\mathrm{CH}_{2}-\mathrm{H}_{4}\right.$ folate $)$ in a reaction that is freely reversible [6], as shown in (6).

$$
\mathrm{E} \cdot \mathrm{FAD}_{\text {red }}+\mathrm{CH}_{2}-\mathrm{H}_{4} \text { folate } \leftrightarrow \mathrm{E} \cdot \mathrm{FAD}_{\text {ox }}+\mathrm{CH}_{3}-\mathrm{H}_{4} \text { folate }
$$

The reversibility of the reaction shown in (6) has been exploited in the standard assay for MTHFR $[1,2,5]$, in which oxidation of $\left[5^{-}{ }^{3} \mathrm{H}\right.$ methyl $] \mathrm{CH}_{3}-\mathrm{H}_{4}$ folate to $\mathrm{CH}_{2}-$ $\mathrm{H}_{4}$ folate is coupled to the reduction of menadione to menadiol, and the resultant $\mathrm{CH}_{2}-\mathrm{H}_{4}$ folate is subjected to acid decomposition in the presence of dimedone. In acid, $\mathrm{CH}_{2}-\mathrm{H}_{4}$ folate decomposes to form $\left[{ }^{3} \mathrm{H}\right]$-formaldehyde, and the formaldehyde-dimedone complex is extracted into toluene for quantitation of product formation.

Stereochemical and kinetic analyses of the reactions catalyzed by the porcine enzyme have shown that both $\mathrm{NADPH}$ and $\mathrm{CH}_{2}-\mathrm{H}_{4}$ folate react at the si face of the enzyme-bound flavin [8], which is depicted in Figure 1. While X-ray structures have been determined for a variety of NADPH-dependent flavoprotein oxidoreductases [9-11], the majority of these proteins bind one or more of their substrates at the re face of the flavin [12]. Thus, the sequence motifs that have been identified in these proteins as being associated with flavin binding may not be the same for MTHFR.

Kutzbach and Stokstad [5] initially demonstrated that mammalian MTHFR activity is regulated by the AdoMet/adenosylhomocysteine ratio, with AdoMet inhibiting enzyme activity and inhibition being relieved by adenosylhomocysteine. Thus, the activity of MTHFR is adjusted in accord with the demand for methyl groups for biological methylation reactions. AdoMet binding to MTHFR results in a conformational change to a form of enzyme with decreased affinity for NADPH. NADPH and AdoMet play antagonistic roles in this regulation, with NADPH recruiting the active forms of the enzyme, and AdoMet recruiting inactive forms [13].

The native porcine MTHFR is a homodimer of 77 $\mathrm{kDa}$ subunits, but when shadowed preparations of the individual dimers are viewed in the scanning transmission electron microscope they show four clear lobes of density, rather than two [14]. These observations suggested that each subunit might contain two distinct regions. Limited proteolysis of the native enzyme with trypsin indeed results in cleavage of the $77 \mathrm{kDa}$ subunit into 40 and $37 \mathrm{kDa}$ fragments, and cleavage is associated with the loss of inhibition by AdoMet, but the activity of the enzyme is unaffected [14]. Photoaffinity labeling of the enzyme with 8-azido-S-adenosylmethionine results in specific labeling of the C-terminal 37 $\mathrm{kDa}$ region [15].

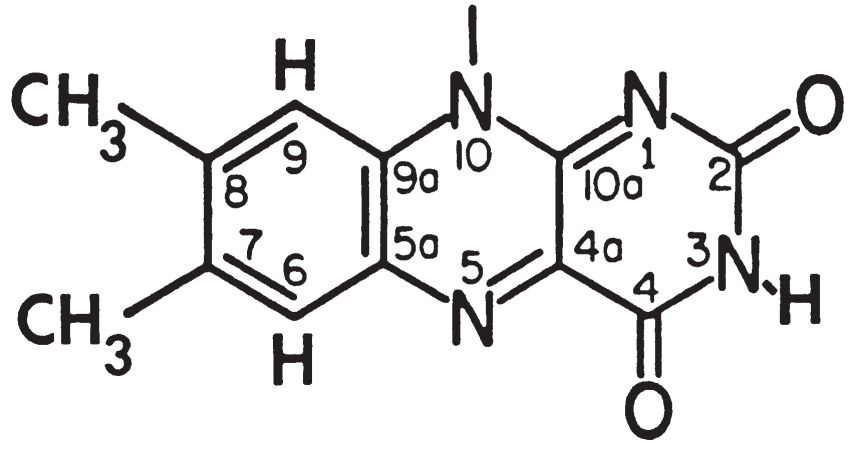

Figure 1. The structure of the isoalloxazine ring of flavin adenine dinucleotide as viewed from the si face, where both substrates of porcine liver methylenetetrahydrofolate reductase, $\mathrm{NAD}(\mathrm{P}) \mathrm{H}$ and $\mathrm{CH}_{2}-\mathrm{H}_{4}$ folate, react.

The isolation of a cDNA coding for the human MTHFR and its recent sequencing [16,17] have provided considerable insight into the organization of the enzyme. The deduced amino acid sequence for this cDNA is shown in Figure 2, and corresponds to a molecular mass of 74,546 kDa. Underlined in Figure 2 are residues corresponding to peptides isolated from homogeneous porcine enzyme and sequenced by Edman degradation. The N-terminal sequence of the porcine enzyme does not appear in the human cDNA, which may indicate that the cDNA isolated codes for a smaller isozyme of MTHFR or perhaps lacks sequence at the 5 '-end.

In one experiment, the native porcine enzyme was first digested with trypsin and the $\mathrm{N}$ - and C-terminal fragments were separated by gel electrophoresis under denaturing conditions. The isolated fragments were cleaved with lysyl endoprotease (LysC), which cleaves the amide bond on the C-terminal side of lysyl residues. Peptides that were derived from the $40 \mathrm{kDa}$ Nterminal fragment correspond to residues 61-94, 219240, and 337-351 [16], while peptides that were derived from the $37 \mathrm{kDa} \mathrm{C}$-terminal fragment correspond to residues 374-394, 420-445, 469-492, 531-543, and 598628 (JS Sumner and RG Matthews, unpublished data). These sequences define the cleavage point between the 40 and $37 \mathrm{kDa}$ fragments as lying between residues 351 and 374 . The sequence in this region with the greatest hydrophilicity and surface probability is K357RREED, and this is the probable site of cleavage of the native enzyme. The predicted mass of the C-terminal fragment generated by cleavage between lysine357 and arginine358 is $34,863 \mathrm{Da}$, in moderately good agreement with the $37 \mathrm{kDa}$ mass observed after cleavage of the porcine enzyme. 


\begin{tabular}{|c|c|c|c|c|c|c|c|c|c|c|c|}
\hline & & & MVNE & ARGNS & SLNPC & LEGSA & SSGSE & SSKDS & SRCST & mthfr & $(1-34)$ \\
\hline $\begin{array}{r}\text { PGLDP } \\
\mathrm{ms} \\
\mathrm{ms}\end{array}$ & $\begin{array}{r}\text { ERHER } \\
\text { ffHas } \\
\text { ffHan }\end{array}$ & $\begin{array}{r}\text { LREKM } \\
\text { qRdal } \\
\text { qREal }\end{array}$ & $\begin{array}{r}\text { RRRLE } \\
\text { nqsLa } \\
\text { nqsLa }\end{array}$ & $\begin{array}{l}\text { S--GD } \\
\text { evqGq } \\
\text { evqGq }\end{array}$ & $\begin{array}{r}\text { KWESL } \\
\text { invSf } \\
\text { invSf }\end{array}$ & $\begin{array}{l}\text { EFFPP } \\
\text { EFFPP } \\
\text { EFFPP }\end{array}$ & $\begin{array}{l}\text { RTAEG } \\
\text { RTsEm } \\
\text { RTsEm }\end{array}$ & $\begin{array}{l}\text { AVNLI } \\
\text { eqtLw } \\
\text { eqtLw }\end{array}$ & $\begin{array}{c}\text { SRFDR } \\
\text { nsiDR } \\
\text { nsidR }\end{array}$ & $\begin{array}{l}\text { mthfr } \\
\text { ecometF } \\
\text { stymetF }\end{array}$ & $(35-82)$ \\
\hline $\begin{array}{r}\text { MAAGG } \\
\begin{array}{r}\text { Iss|k } \\
\text { Isslk }\end{array}\end{array}$ & $\begin{array}{l}\frac{\text { PLYID }}{\text { Pkfvs }} \\
\text { Pkfvs }\end{array}$ & $\begin{array}{c}\text { VTWHP } \\
\text { VTy-- } \\
\text { VTy-- }\end{array}$ & $\begin{array}{r}\text { AGDPG } \\
\text { gansG } \\
\text { gansG }\end{array}$ & $\begin{array}{r}\text { SDKET } \\
\text { erdrT } \\
\text { erdrT }\end{array}$ & $\begin{array}{r}\text { SSMMI } \\
\text { hSi-I } \\
\text { hSv-I }\end{array}$ & $\begin{array}{r}\text { ASTAV } \\
\text { kgik- } \\
\text { kgik- }\end{array}$ & $\begin{array}{r}\text { NYCGL } \\
\text { drtGL } \\
\text { ertGL }\end{array}$ & $\begin{array}{l}\text { ETILH } \\
\text { EaapH } \\
\text { EaapH }\end{array}$ & $\begin{array}{l}\text { MTCCR } \\
\text { ITCid } \\
\text { ITCid }\end{array}$ & $\begin{array}{l}\text { mthfr } \\
\text { ecometF } \\
\text { stymetF }\end{array}$ & $(83-132)$ \\
\hline $\begin{array}{r}\text { QRLEE } \\
\text { atpdE } \\
\text { atrdE }\end{array}$ & $\begin{array}{r}\text { ITGHL } \\
\text { Irtia } \\
\text { Irtia }\end{array}$ & $\begin{array}{r}\text { HKAKQ } \\
\text { rdywn } \\
\text { rdywn }\end{array}$ & $\begin{array}{c}\text { LGLKN } \\
\text { nGirh } \\
\text { nGirh }\end{array}$ & $\begin{array}{l}\text { IMALR } \\
\text { IVALR } \\
\text { IVALR }\end{array}$ & $\begin{array}{c}\text { R157-> Q } \\
\text { GD-PI } \\
\text { GDIPp } \\
\text { GDIPp }\end{array}$ & $\begin{array}{r}\text { GDQW- } \\
\text { Gsgkp } \\
\text { Gsgkp }\end{array}$ & $\begin{array}{c}-- \text { EEE } \\
----- \\
---\end{array}$ & $\begin{array}{r}\text { EGGFN } \\
--- \text { em } \\
---e m\end{array}$ & $\begin{array}{l}\text { YAVGL } \\
\text { YAsdL } \\
\text { YAadL }\end{array}$ & $\begin{array}{l}\text { mthfr } \\
\text { ecometF } \\
\text { stymetF }\end{array}$ & (133-178 \\
\hline $\begin{array}{r}\text { VKHIR } \\
\text { Vtllk } \\
\text { Vgllk }\end{array}$ & $\begin{array}{r}\text { SEFGD } \\
\text {-EvaD } \\
\text {-EvaD }\end{array}$ & $\begin{array}{r}\text { YFDIC } \\
\text {-FDIs } \\
\text {-FDIs }\end{array}$ & $\begin{array}{l}\text { VAGYP } \\
\text { VAaYP } \\
\text { VAaYP }\end{array}$ & $\begin{array}{l}\text { KGH-- } \\
\text { evH-- } \\
\text { evH-- }\end{array}$ & $\begin{array}{l}\text { PEAGS } \\
\text { PEAkS } \\
\text { PEAkS }\end{array}$ & $\begin{array}{l}\text { FEA-- } \\
\text { aqA-- } \\
\text { aqA-- }\end{array}$ & $\begin{array}{l}--D L K \\
--D L I \\
--D L I\end{array}$ & $\begin{array}{c}\text { ·22 } \\
\text { HLKEK } \\
\text { nLKrK } \\
\text { nLKrK }\end{array}$ & $\begin{array}{l}2->V \\
\text { VSAGA } \\
\text { VdAGA } \\
\text { VdAGA }\end{array}$ & $\begin{array}{l}\text { mthfr } \\
\text { ecometF } \\
\text { stymetF }\end{array}$ & 175 \\
\hline $\begin{array}{l}\text { DFIIT } \\
\text { nralT } \\
\text { nralT }\end{array}$ & $\begin{array}{c}\text { T227 > M } \\
\text { QLFFE } \\
\text { QfFFd } \\
\text { QfFFd }\end{array}$ & $\begin{array}{r}\text { ADTFF } \\
\text { vesyl } \\
\text { vesyl }\end{array}$ & $\begin{array}{l}\text { REVKA } \\
\text { RFrdr } \\
\text { RFrdr }\end{array}$ & $\begin{array}{r}\text { CTDMG } \\
\text { CvsaG } \\
\text { CrsaG }\end{array}$ & $\begin{array}{l}\text { IT-CP } \\
\text { Id-ve } \\
\text { Id-ve }\end{array}$ & $\begin{array}{r}\text { IVPGI } \\
\text { liPGI } \\
\text { liPGI }\end{array}$ & $\begin{array}{l}\text { FPI-Q } \\
\text { IPV-S } \\
\text { IPv-s }\end{array}$ & $\begin{array}{r}\text { GYHSL } \\
\text { nfkqa } \\
\text { nfkqa }\end{array}$ & $\begin{array}{r}\text { RQLVK } \\
\text { kkfad } \\
\text { kkfad }\end{array}$ & $\begin{array}{l}\text { mthfr } \\
\text { ecometF } \\
\text { stymetF }\end{array}$ & $(223-270)$ \\
\hline $\begin{array}{c}\text { LSKLE } \\
\text { mtnvr } \\
\text { mtnvr }\end{array}$ & $\begin{array}{l}\text { VPQEI } \\
\text { iPawm } \\
\text { iPswm }\end{array}$ & $\begin{array}{l}\text { KDVIE } \\
\text { aqmfd } \\
\text { slmfE }\end{array}$ & $\begin{array}{l}\text { P-IKD } \\
\text { gl-Dd } \\
\text { gl-Dn }\end{array}$ & $\begin{array}{l}\text { NDAAI } \\
\text { daetr } \\
\text { daetr }\end{array}$ & $\begin{array}{r}\text { RNYGI } \\
\text { klvGa } \\
\text { klvGa }\end{array}$ & $\begin{array}{l}\text { ELAVS } \\
\text { niAmd } \\
\text { niAmd }\end{array}$ & $\begin{array}{c}\text { LCQEL } \\
\text { mvkiL } \\
\text { mvkiL }\end{array}$ & $\begin{array}{c}\text { LASGL } \\
\text { sreG- } \\
\text { sreG- }\end{array}$ & $\begin{array}{l}--V P G \\
--V k d \\
--V k d\end{array}$ & $\begin{array}{l}\text { mthfr } \\
\text { ecometF } \\
\text { stymetF }\end{array}$ & $(271-31)$ \\
\hline $\begin{array}{l}\text { LHFYT } \\
\text { fHFYT } \\
\text { fHYFT }\end{array}$ & $\begin{array}{l}\text { LNR-E } \\
\text { LNRaE } \\
\text { LNRaE }\end{array}$ & $\begin{array}{l}\text { MATTE } \\
\text { Msya- } \\
\text { Msya- }\end{array}$ & $\begin{array}{r}\text { VLKRL } \\
\text { ichtL } \\
\text { ichtL }\end{array}$ & $\begin{array}{r}\text { GMWTEE } \\
\text { Gvrpg } \\
\text { Gurpg }\end{array}$ & $\begin{array}{l}\text { DPRRP } \\
\mid> \\
\mid>\end{array}$ & LPWAL & SAHPK & RREED & VRPIF & $\begin{array}{l}\text { mthfr } \\
\text { ecometF } \\
\text { stymetF }\end{array}$ & 318 \\
\hline ASRP & KSYIY & RTOEW & DEFPN & GRWGN & SSSPA & GELK & YYLF & YLKSK & SPKEE & mthfr & 416 \\
\hline LLKMW & GEEELT & SEASV & FEVFV & LYLSG & EPNRN & HKVT & CLPWN & DEPLA & AETSL & nthfr & $(417-466)$ \\
\hline LKEEL & LRVNR & QGILT & INSOP & NINGK & PSSDP & IVGWG & PSGGY & VFQKA & YLEFF & thfir & $(467-516)$ \\
\hline TSRET & AEALL & QVLKK & YELRV & NYHLV & NVKGE & NITNA & PELQP & NAVTW & GIFPG & mthfr & $(517-566)$ \\
\hline REIIQ & PTVVD & PVSFM & FWKDE & AFALW & IERWG & KLYEE & ESPSR & TIIQY & $\underline{\text { IHDNY }}$ & mthfr & $(567-616)$ \\
\hline$\underline{\text { FLVNL }}$ & VDNDF & PLDNC & LWQVV & EDTLE & LLNRP & TQNAR & ETEAP> & & & mthfr & $(617-656)$ \\
\hline
\end{tabular}

Figure 2. Alignment of the deduced amino-acid sequence of human methylenetetrahydrofolate reductase [16,17], designated mthfr, with the deduced amino acid sequences of the MetF proteins from E. coli [19] and S. typhimurium [20], designated ecometF and stymetF, respectively. Underlined residues indicate identities with residues in peptides isolated from porcine liver methylenetetrahydrofolate reductase. Residues shown in bold are identical in all three deduced sequences. Bullets indicate the locations of three mutations that are associated with homocysteinemia in humans and that affect conserved residues in the aligned sequences. The numbering of the mthfr amino acid sequence assumes that the ATG codon in the cDNA beginning at nt 13 of the published sequence [16] is the initiator site for translation of the protein.

Properties of the Bacterial Methylenetetrahydrofolate Reductase Enzymes

Figure 2 also shows the alignment of the deduced amino acid sequence of human MTHFR with the sequences of the methylenetetrahydrofolate reductases from Escherichia coli and Salmonella typhimurium. These aligned sequences show $24 \%$ identity, so that the three- dimensional structures of the bacterial enzymes and the $\mathrm{N}$-terminal region of the human enzyme are almost certainly highly similar. The MTHFR from Escherichia coli was initially characterized by Buchanan and his colleagues [3]. This enzyme was shown to be a flavoprotein, and was shown to catalyze the reduction of $\mathrm{CH}_{2}-\mathrm{H}_{4}$ folate to $\mathrm{CH}_{3}-\mathrm{H}_{4}$ folate. In contrast to the mammalian enzymes, the bacterial enzyme activity is not 
regulated by adenosylmethionine, in agreement with the lack of a C-terminal regulatory domain. This protein is encoded by the metF gene in both $E$. coli and $S$. typhimurium. The metF gene from both organisms has been sequenced $[19,20]$. We have succeeded in constructing an expression vector for overproduction of MTHFR from Escherichia coli plasmid pEJ3-1B, which contains the metF gene in a pBR322 plasmid [20]. In our vector, pCAS-5, the MTHFR coding sequence is placed under the control of the trc promoter, and approximately $20 \%$ of the total cellular protein is MTHFR when cells are grown in the presence of IPTG. We have recently purified the wild type bacterial enzyme to homogeneity, and have confirmed that the MTHFR protein is a flavoprotein. The homogenous enzyme exhibits both $\mathrm{CH}_{3}-\mathrm{H}_{4}$ folate-menadione oxidoreductase activity (7),

$$
\mathrm{CH}_{3}-\mathrm{H}_{4} \text { folate }+ \text { menadione } \rightarrow \mathrm{CH}_{2}-\mathrm{H}_{4} \text { folate }+ \text { menadiol }
$$

and NADH-menadione oxidoreductase activity (8).

$$
\mathrm{NADH}+\text { menadione } \rightarrow \mathrm{NAD}^{+}+\text {menadiol }
$$

Initial studies of partially purified MTHFR enzyme had indicated that NADH could supply reducing equivalents for the reduction of $\mathrm{CH}_{2}-\mathrm{H}_{4}$ folate, but further purification of the enzyme by Katzen and Buchanan resulted in the loss of NADH-CH$-\mathrm{H}_{4}$ folate oxidoreductase activity [3]. However, in our enzyme preparations NADH-menadione oxidoreductase activity copurifies with $\mathrm{CH}_{3}-\mathrm{H}_{4}$ folate-menadione oxidoreductase activity, and we presume that the physiologic reaction is given by (9).

$$
\mathrm{NADH}+\mathrm{CH}_{2}-\mathrm{H}_{4} \text { folate } \rightarrow \mathrm{NAD}^{+}+\mathrm{CH}_{3}-\mathrm{H}_{4} \text { folate }
$$

Thus, the bacterial enzymes are able to bind FAD and catalyze the transfer of reducing equivalents from $\mathrm{NADH}$ to the enzyme-bound flavin and from reduced flavin to $\mathrm{CH}_{2}-\mathrm{H}_{4}$ folate. Since these enzymes are only $\sim 33 \mathrm{kDa}$ (296 amino acids), the corresponding region of the human enzyme is likely to contain the residues necessary for FAD, NADPH, and $\mathrm{CH}_{2}-\mathrm{H}_{4}$ folate binding. Thus the catalytic domain of the human enzyme is probably located in the N-terminal $40 \mathrm{kDa}$ region, while regulation by AdoMet is likely to require the C-terminal domain. The sequence alignment indicates several highly conserved regions of sequence, which are likely to contain residues critical to the binding of substrates and FAD, and to catalysis of oxidoreduction of the substrates.
Mutations Associated with Homocysteinemia in Humans and the Phenotypes of the Corresponding Bacterial Mutations

A number of mutations of human MTHFR that are associated with human disease have now been identified $[16,17,21]$. A subset of these mutations affect residues that are identical in the sequences of the bacterial enzymes aligned in Figure 2. These mutations include Arg157Gln [16] and Thr227Met, as well as the polymorphism Ala222Val. In humans, the Thr227Met mutation in a homozygous state is associated with extremely low levels of activity (0-3\%) and onset of symptoms within the first year after birth [21]. Thus far, the only patients with the Arg157Gln mutation are heterozygotes, with an uncharacterized second mutation $[16,21]$. These patients have $>6 \%$ residual activity and develop symptoms only during or after the second decade of life.

The Ala222Val polymorphism is thought to be associated with mild homocysteinemia in humans [17]. Homocysteinemia has been identified as an independent risk factor for cardiovascular disease [22]. Indeed, Kang and his colleagues [23] have described the association of a mild MTHFR deficiency, with increased thermolability, with increased risk for coronary artery disease. At the time this work was published, the sequence of MTHFR was not known, and so the mutation(s) responsible for this phenotype could not be not identified. Because the catalytic mechanism and tertiary structure of the N-terminal region of the human enzyme is likely to be very similar to those of the bacterial enzymes, we have undertaken the construction and expression of mutations that correspond to Arg157Gln, Thr227Met, and Ala222 Val in the E. coli enzyme. Characterization of these mutant enzymes is now in progress.

Acknowledgments - This work has been supported by National Institutes of Health Grant R37-GM24908 (RGM) and by the Medical Research Council of Canada (RR).

\section{References}

1. Donaldson KO, Keresztesy JC. Naturally occurring forms of folic acid: I. "Prefolic A": Preparation of concentrate and enzymatic conversion to citrovorum factor. J Biol Chem 234:3235-3240, 1959.

2. Donaldson KO, Keresztesy JC. Naturally occurring forms of folic acid: II. Enzymatic conversion of methylenetetrahydrofolic acid to prefolic A-methyltetrahydrofolate. J Biol Chem 237:1298-1304, 1962.

3. Katzen HM, Buchanan JM. Enzymatic synthesis of the methyl group of methionine: VIII. Repression, derepression, purification, and properties of 5,10-methylenetetrahydrofolate reductase from Escherichia coli. J Biol Chem 240:825-835, 1965. 
4. Clark JE, Ljungdahl LG. Purification and properties of 5,10-methylenetetrahydrofolate reductase, an iron-sulfur flavoprotein from Clostridium formicoaceticum. J Biol Chem 259:10845-10849, 1984.

5. Kutzbach C, Stokstad ELR. Mammalian methylenetetrahydrofolate reductase: Partial purification, properties, and inhibition by S-adenosylmethionine. Biochim Biophys Acta 250:459-477, 1971.

6. Daubner SC, Matthews RG. Purification and properties of methylenetetrahydrofolate reductase from pig liver. In: Massey V, Williams $\mathrm{CH}$ (eds.) Flavins and Flavoproteins. New York: Elsevier Science, 1982, pp. 165-172.

7. Green JM, Ballou DP, Matthews RG. Examination of the role of methylenetetrahydrofolate reductase in incorporation of methyltetrahydrofolate into cellular metabolism. FASEB J 2:42-47, 1988.

8. Sumner JS, Matthews RG. Stereochemistry and mechanism of hydrogen transfer between NADPH and methylenetetrahydrofolate in the reaction catalyzed by methylenetetrahydrofolate reductase from pig liver. J Am Chem Soc 114:6949-6956, 1992.

9. Correll CC, Ludwig ML, Bruns CM, Karplus PA. Structural prototypes for an extended family of flavoprotein reductases: Comparison of phthalate dioxoygenase with ferredoxin reductase and ferredoxin. Protein Science 2:21122133, 1993.

10. Thieme R, Pai EF, Schirmer RH, Schuiz GE. The three-dimensional structure of glutathione reductase at $2 \AA$ resolution. J Mol Biol 152:763-782, 1981.

11. Mathews FS. New flavoenzymes. Curr Opin Struct Biol 1:954-967, 1991.

12. Pai EF. The stereochemistry of the prosthetic groups of flavoproteins. In: Muller F (ed.) Chemistry and Biochemistry of Flavoenzymes Vol. III. Boca Raton, FL: CRC Press, 1992, pp. 357-366.

13. Jencks DA, Matthews RG. Allosteric inhibition of methylenetetrahydrofolate reductase by adenosylmethionine: Effects of adenosylmethionine and NADPH on the equilibrium between active and inactive forms of the enzyme and on the kinetics of approach to equilibrium. J Biol Chem 262:2485-2493, 1987.
14. Matthews RG, Vanoni MA, Hainfeld JA, Wall J. Methylenetetrahydrofolate reductase: Evidence for spatially distinct subunit domains obtained by scanning transmission electron microscopy and limited proteolysis. J Biol Chem 259:11647-11650, 1984.

15. Sumner J, Jencks DA, Khani S, Matthews RG. Photoaffinity labeling of methylenetetrahydrofolate reductase with 8-azido-S-adenosylmethionine. J Biol Chem 261:7697-7700, 1986.

16. Goyette P, Sumner JS, Milos R et al. Human methylenetetrahydrofolate reductase: Isolation of cDNA, mapping and mutation identification. Nature Genetics 7:195-200, 1994.

17. Frosst P, Blom HJ, Milos R et al. Identification of a candidate genetic risk factor for vascular disease: A common mutation in the methylenetetrahydrofolate reductase gene. Nature Genetics 10:111-113, 1995.

18. Sumner JS, Matthews RG. Unpublished data, 1995.

19. Saint-Girons I, Duchange N, Zakin MM et al. Nucleotide sequence of metF, the E. coli structural gene for 5,10-methylenetetrahydrofolate reductase and of its control region. Nucleic Acids Res 11:6723-6732, 1983.

20. Stauffer GV, Stauffer LT. Cloning and nucleotide sequence of the Salmonella typhimurium LT2 metF gene and its homology with the corresponding sequence of Escherichia coli. Mol Gen Genet 212:246-251, 1988.

21. Emmett MR, Johnson JR. Control of metF gene expression in maxicell preparations of Escherichia coli K-12: Reverible action of the metJ protein and effect of vitamin $\mathrm{B}_{12}$.J Bacteriol 168:1491-1494, 1986.

22. Goyette P, Frosst P, Rosenblatt DS, Rozen R. Seven novel mutations in the methylenetetrahydrofolate reductase gene and genotype/phenotype correlations in severe methylenetetrahydrofolate reductase deficiency. Am J Hum Genet 56:1052-1059, 1995.

23. Clarke R, Daly L, Robinson K et al. Hyperhomocysteinemia: An independent risk factor for vascular disease. $N$ Engl J Med 324:1149-1155, 1991.

24. Kang S-S, Wong PWK, Susmano A, Sora J, Norusis M, Ruggie N. Thermolabile methylenetetrahydrofolate reductase: An inherited risk factor for coronary artery disease. Am J Hum Genet 48:536 - 545, 1991. 